\title{
Article \\ Effective Magnetic MOFs Adsorbent for the Removal of Bisphenol A, Tetracycline, Congo Red and Methylene Blue Pollutions
}

\author{
Guangpu Zhang ${ }^{1}$, Rong Wo ${ }^{1}$, Zhe Sun ${ }^{1}$, Gazi Hao ${ }^{1}$, Guigao Liu ${ }^{1}$, Yanan Zhang ${ }^{2, *}$, Hu Guo ${ }^{1, *}$ (i) and Wei Jiang ${ }^{1}$ \\ 1 National Special Superfine Powder Engineering Research Center of China, School of Chemistry and Chemical \\ Engineering, Nanjing University of Science and Technology, Nanjing 210094, China; \\ gpzhang@njust.edu.cn (G.Z.); worong0614@163.com (R.W.); sunzhe97529@163.com (Z.S.); \\ hgznjust1989@163.com (G.H.); guigao.liu@njust.edu.cn (G.L.); superfine_jw@126.com (W.J.) \\ 2 College of Materials Science and Engineering, Nanjing Tech University, Nanjing 211816, China \\ * Correspondence: zyn3648@njtech.edu.cn (Y.Z.); guohu21@njust.edu.cn (H.G.)
}

check for updates

Citation: Zhang, G.; Wo, R.; Sun, Z.; Hao, G.; Liu, G.; Zhang, Y.; Guo, H.; Jiang, W. Effective Magnetic MOFs Adsorbent for the Removal of Bisphenol A, Tetracycline, Congo Red and Methylene Blue Pollutions. Nanomaterials 2021, 11, 1917. https:// doi.org/10.3390/nano11081917

Academic Editors: Lyudmila M. Bronstein and Yurii K. Gun'ko

Received: 21 May 2021

Accepted: 23 July 2021

Published: 26 July 2021

Publisher's Note: MDPI stays neutral with regard to jurisdictional claims in published maps and institutional affiliations.

\begin{abstract}
A magnetic metal-organic frameworks adsorbent $\left(\mathrm{Fe}_{3} \mathrm{O}_{4} @ \mathrm{MIL}-53(\mathrm{Al})\right)$ was prepared by a typical solvothermal method for the removal of bisphenol A (BPA), tetracycline (TC), congo red $(\mathrm{CR})$, and methylene blue (MB). The prepared $\mathrm{Fe}_{3} \mathrm{O}_{4} @ \mathrm{MIL}-53(\mathrm{Al})$ composite adsorbent was well characterized by scanning electron microscope (SEM), transmission electron microscope (TEM), X-ray diffraction (XRD), and fourier transform infrared spectrometer (FTIR). The influence of adsorbent quantity, adsorption time, $\mathrm{pH}$ and ionic strength on the adsorption of the mentioned pollutants were also studied by a UV/Vis spectrophotometer. The adsorption capacities were found to be $160.9 \mathrm{mg} / \mathrm{g}$ for BPA, $47.8 \mathrm{mg} / \mathrm{g}$ for TC, $234.4 \mathrm{mg} / \mathrm{g}$ for CR, $70.8 \mathrm{mg} / \mathrm{g}$ for MB, respectively, which is superior to the other reported adsorbents. The adsorption of BPA, TC, and CR were well-fitted by the Langmuir adsorption isotherm model, while MB followed the Freundlich model, while the adsorption kinetics data of all pollutants followed the pseudo-second-order kinetic models. The thermodynamic values, including the enthalpy change $\left(\Delta H^{\circ}\right)$, the Gibbs free energy change $\left(\Delta G^{\circ}\right)$, and entropy change $\left(\Delta S^{\circ}\right)$, showed that the adsorption processes were spontaneous and exothermic entropy-reduction process for BPA, but spontaneous and endothermic entropy-increasing processes for the others. The $\mathrm{Fe}_{3} \mathrm{O}_{4} @ \mathrm{MIL}-53(\mathrm{Al})$ was also found to be easily separated after external magnetic field, can be a potential candidate for future water treatment.
\end{abstract}

Keywords: magnetic; metal-organic framework; adsorption; water treatment

\section{Introduction}

Environmental pollution, especially water pollution caused by dyes, has drawn public and scientific attention in recent years. Exposure to hazardous organic dyes, which are widely used in the agriculture and textile industries, cause severe water shortages and ecological damages [1,2]. In addition to controlling the discharge of wastewater, it is necessary to remove as many contaminants as possible before discharge. To this end, methods have been developed for treating pollutants in water, including electrochemical [3-5], redox [6,7], coagulation [8,9], and photocatalytic methods [10,11]. However, these strategies require complex processes and expensive instruments and have technical limitations that require them to be combined with complementary methods to remove low concentrations of pollutants. Adsorption provides a simple, efficient and low-cost method for water treatment [10,12-15]. Traditional adsorbents, such as activated carbon, zeolites, silica microspheres and natural fibers, have been used for the adsorptive removal of pollutants; however, their applications are limited due to their insufficient adsorption capacity, relatively low thermochemical stability, and poor reproducibility [16]. Accordingly, new types of adsorbents should be developed that can remove different types of organic dye. 
Metal-organic frameworks (MOFs) are crystalline materials that are formed via the self-assembly of organic ligands and metal ions. Due to their larger surface area, greater porosity, and tunable pore sizes, MOFs are popular for photocatalysis, electrocatalysis, enzyme immobilization, gas storage, and chemical sensing [17-23]. Recently, MOFs also have been used to treat environmental contaminants. Less-toxic MIL-53( $\mathrm{Al})\left\{\mathrm{Al}(\mathrm{OH})\left[\mathrm{O}_{2} \mathrm{C}-\right.\right.$ $\left.\left.\mathrm{C}_{6} \mathrm{H}_{4}-\mathrm{CO}_{2}\right]\right\}$, which has a high thermal stability, structural flexibility, and a lower-cost, has become a candidate for pollutant treatment $[24,25]$. One promising approach for enhancing the functionality of MOFs is the use of a magnetic composite structure [26,27]. This type of hybrid adsorbent can facilitate the recycling of MOFs after dye adsorption because they can simply be separated using an external magnetic field; therefore, preparing magnetic MOF composites has a significance for adsorption and separation of pollutants [28,29].

The solvothermal method is a typical method to prepare the metal-organic framework materials. Most MOFs are synthesized by this method. The solvothermal method is the metal ions and organic ligand dissolving in organic solvent composite material under high temperature and pressure in the reaction kettle. This method is simple to operate and can prepare the material in one step. Moreover, the crystal construction made by a solvothermal method has fewer defects. Therefore, in this work, a magnetic MOF adsorbent with a structure $\left(\mathrm{Fe}_{3} \mathrm{O}_{4} @ \mathrm{MIL}-53(\mathrm{Al})\right)$ was designed and prepared by a solvothermal method and then used to remove four representative pollutants bisphenol A (BPA), tetracycline (TC), congo red (CR), and methylene blue (MB). Due to the porous structure of MIL-53(Al) and the presence of magnetic $\mathrm{Fe}_{3} \mathrm{O}_{4}$ particles, the $\mathrm{Fe}_{3} \mathrm{O}_{4} @ \mathrm{MIL}-53(\mathrm{Al})$ composite adsorbent effectively treated wastewater and could be reused after removal by an external magnetic field. The influence of the adsorbent quantity, adsorption time, $\mathrm{pH}$, ionic strength, and other factors on the adsorption was also explored. The adsorption properties of the target pollutants, including kinetics, isotherms, and thermodynamics, were also discussed.

\section{Experimental}

\subsection{Materials}

Table 1 shows a list of the empirical formula, suppliers, molecular weight and purity of the chemicals used in this work. Ferric chloride $\left(\mathrm{FeCl}_{3} \cdot 6 \mathrm{H}_{2} \mathrm{O}\right)$, ethylene glycol, anhydrous sodium acetate ( $\mathrm{NaAc}$ ), $\mathrm{N}, \mathrm{N}$-dimethylformamide (DMF), methyl alcohol, sodium hydroxide, and hydrochloric acid were purchased from Sinopharm Chemical Reagent Co., Ltd., Beijing, China. Trisodium citrate dihydrate and aluminum nitrate nonahydrate were obtained from Xilong Scientific Co., Ltd., Guangzhou, China. 1,4-Dicarboxybenzene was purchased from Nanjing Wanqing Pharm. Co., Ltd., Nanjing, China. Bisphenol A was supplied by Shanghai Aladdin BioChem Technology Co., Ltd., Shanghai, China. Tetracycline was purchased from Nanjing Jiaozi Rattan Scientific Instrument Co., Ltd., Nanjing, China. Congo red (CR), methylene blue $(\mathrm{MB})$, and sodium chloride $(\mathrm{NaCl})$ were obtained from Chengdu Kelong Chemical Industry, Chengdu, China. Absolute ethyl alcohol was purchased from Nanjing Chemical Reagent Co., Ltd., Nanjing, China. All reagents and solvents were used as received without further purification.

\subsection{Characterization}

The crystal structure of the synthesized adsorbent was examined by XRD (D8 Advance, Bruker, Karlsruhe, Germany), using $\mathrm{Cu} \mathrm{K}_{\alpha}$ radiation in the range of 5-80 $(2 \theta)$, voltage of $40 \mathrm{kV}$, current of $40 \mathrm{~mA}$ and wavelength of $1.54 \AA$. The specific procedure involved taking a small sample and compacting it on a glass sheet and then placing it into the instrument for analysis. Fourier-transform infrared (FT-IR) spectra were recorded in the solid-state (KBr pellet) using a Vector 22 spectrophotometer (Bruker). The spectral scanning range was $4000 \mathrm{~cm}^{-1}-500 \mathrm{~cm}^{-1}$, the resolution was $4 \mathrm{~cm}^{-1}$, and the number of scans was 32 . The transmission electron microscope (TEM) was carried out to observe the particle size and morphology. The specific procedure involved taking a small amount of prepared samples and dispersing them in anhydrous ethanol with a toothpick. Then, samples were ultrasonicated to fully disperse the particles, and then a few drops of suspension were 
extracted with a dropper and dropped them into a copper grid. TEM images were obtained after the liquid evaporated. The size and morphology of $\mathrm{Fe}_{3} \mathrm{O}_{4} @ \mathrm{MIL}-53(\mathrm{Al})$ were also observed with a Scanning electron microscope (SEM) EM (Model-S480 II FESEM). The specific procedure involved extracting a few dried samples with a toothpick and sticking them on a conductive adhesive. After spraying in gold, they were placed into the SEM for analysis. The magnetic saturation strength of the samples was tested by vibrating sample magnetometry (VSM) (LakeShore 735) with the test magnetic moment range of $-20-20 \mathrm{kOe}$. The specific procedure is as follows: take about $20 \mathrm{mg}$ sample and put it into a plastic tube, plug the two ends with cotton, and then put it into the instrument for testing. A UV/Vis spectrophotometer (Agilent Cary 100 UV-2600, Santa Clara, CA, USA) was used to measure the dye concentrations in the solution. The spectral range was $200-800 \mathrm{~nm}$.

Table 1. Empirical Formula, CAS Registry Number, Suppliers, and Purity of the Chemicals.

\begin{tabular}{|c|c|c|c|c|}
\hline Component & Chemicals & $\begin{array}{c}\text { Molecular } \\
\text { Weight(g/mol) }\end{array}$ & Suppliers & Purity \\
\hline Ferric chloride & $\mathrm{FeCl}_{3} \cdot 6 \mathrm{H}_{2} \mathrm{O}$ & 270.3 & Sinopharm Chemical Reagent Co., Ltd. & A.R \\
\hline ethylene glycol & $\mathrm{C}_{2} \mathrm{H}_{6} \mathrm{O}_{2}$ & 62.1 & Sinopharm Chemical Reagent Co., Ltd. & A.R \\
\hline anhydrous sodium acetate & $\mathrm{CH}_{3} \mathrm{COONa}$ & 82.1 & Sinopharm Chemical Reagent Co., Ltd. & A.R \\
\hline Trisodium citrate dihydrate & $\mathrm{Na}_{3} \mathrm{C}_{6} \mathrm{H}_{5} \mathrm{O}_{7} \cdot 2 \mathrm{H}_{2} \mathrm{O}$ & 294.1 & Xilong Scientific Co., Ltd. & A.R \\
\hline $\mathrm{N}, \mathrm{N}$-dimethylformamide & $\mathrm{C}_{3} \mathrm{H}_{7} \mathrm{NO}$ & 73.1 & Sinopharm Chemical Reagent Co., Ltd. & A.R \\
\hline $\begin{array}{c}\text { aluminum nitrate } \\
\text { nonahydrate }\end{array}$ & $\mathrm{H}_{18} \mathrm{AlN}_{3} \mathrm{O}_{18}$ & 375.1 & Xilong Scientific Co., Ltd. & A.R \\
\hline 1,4-Dicarboxybenzene & $\mathrm{C}_{8} \mathrm{H}_{6} \mathrm{O}_{4}$ & 166.1 & Nanjing Wanqing Pharm. Co., Ltd. & A.R \\
\hline methyl alcohol & $\mathrm{CH}_{3} \mathrm{OH}$ & 32.1 & Sinopharm Chemical Reagent Co., Ltd. & A.R \\
\hline Bisphenol A & $\mathrm{C}_{15} \mathrm{H}_{16} \mathrm{O}_{2}$ & 228.3 & Aladdin BioChem Technology Co., Ltd. & G.C \\
\hline Tetracycline & $\mathrm{C}_{22} \mathrm{H}_{24} \mathrm{~N}_{2} \mathrm{O}_{8}$ & 444.4 & $\begin{array}{c}\text { Nanjing Jia Nanjing Jiaozi Rattan Scientific ozi } \\
\text { Rattan Scientific Instrument Co., Ltd. }\end{array}$ & C.P \\
\hline Congo red & $\mathrm{C}_{32} \mathrm{H}_{22} \mathrm{~N}_{6} \mathrm{Na}_{2} \mathrm{O}_{6} \mathrm{~S}_{2}$ & 696.7 & Chengdu Kelong Chemical Industry & A.R \\
\hline methylene blue & $\mathrm{C}_{16} \mathrm{H}_{18} \mathrm{ClN}_{3} \mathrm{~S}$ & 319.8 & Chengdu Kelong Chemical Industry & A.R \\
\hline sodium chloride & $\mathrm{NaCl}$ & 58.4 & Chengdu Kelong Chemical Industry & A.R \\
\hline sodium hydroxide & $\mathrm{NaOH}$ & 40.0 & Sinopharm Chemical Reagent Co., Ltd. & A.R \\
\hline hydrochloric acid & $\mathrm{HCl}$ & 36.5 & Sinopharm Chemical Reagent Co., Ltd. & A.R \\
\hline deionized water & $\mathrm{H}_{2} \mathrm{O}$ & 18.0 & Laboratory provision & A.R \\
\hline Absolute ethyl alcohol & $\mathrm{C}_{2} \mathrm{H}_{6} \mathrm{O}$ & 46.1 & Nanjing Chemical Reagent Co., Ltd. & A.R \\
\hline
\end{tabular}

Note: A.R is Analytical Reagent; G.C is Gas Chromatographically pure; C.P is Chemically Pure.

\subsection{Preparation of $\mathrm{Fe}_{3} \mathrm{O}_{4} @ M I L-53(\mathrm{Al})$}

As shown in Scheme 1, preparation of carboxylated $\mathrm{Fe}_{3} \mathrm{O}_{4}-\mathrm{COOH}$ particles was carried out as follows. $\mathrm{FeCl}_{3} \cdot 6 \mathrm{H}_{2} \mathrm{O}(1.3 \mathrm{~g}$, $4.8 \mathrm{mmol})$ and Trisodium citrate dihydrate $(0.5 \mathrm{~g}$, $1.7 \mathrm{mmol}$ ) were dissolved in $40 \mathrm{~mL}$ ethylene glycol with ultrasonic stirring for $10 \mathrm{~min}$. Then, sodium acetate $(2.6 \mathrm{~g}, 31.7 \mathrm{mmol})$ was added and ultrasonication was performed for another $30 \mathrm{~min}$. The solution was then transferred to a polytetrafluoroethylene reactor and was reacted at $200{ }^{\circ} \mathrm{C}$ for $8 \mathrm{~h}$. After that, the solution was cooled to an ambient temperature, and the prepared materials were magnetically separated by an external magnetic field, washed alternately with deionized water and ethanol, and dried at $60{ }^{\circ} \mathrm{C}$. The product, carboxylated $\mathrm{Fe}_{3} \mathrm{O}_{4}-\mathrm{COOH}$ particles, was obtained. 


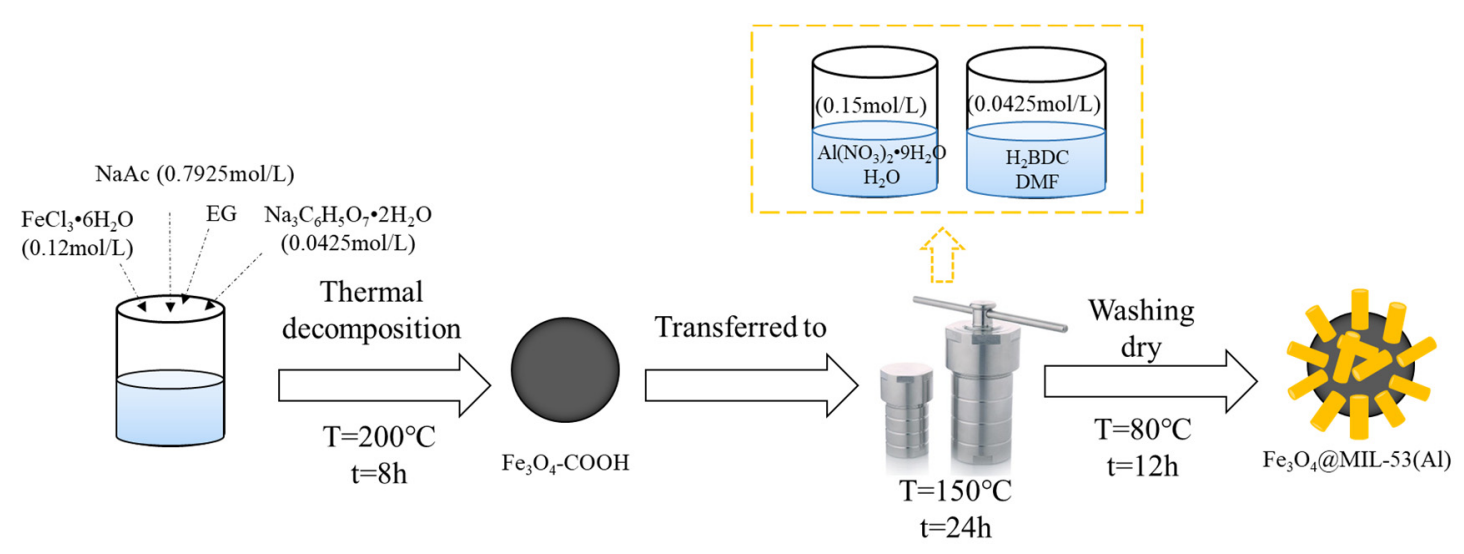

Scheme 1. Illustration of the Preparation Process of $\mathrm{Fe}_{3} \mathrm{O}_{4} @ \mathrm{MIL}-53(\mathrm{Al})(\mathrm{T}=$ Temperature; $\mathrm{t}=$ time).

Magnetic MOFs $\left(\mathrm{Fe}_{3} \mathrm{O}_{4} @ \mathrm{MIL}-53(\mathrm{Al})\right)$ were obtained by the following procedure: Aluminum nitrate nonahydrate $(0.5625 \mathrm{~g}, 1.5 \mathrm{mmol})$ and 1,4-dicarboxybenzene $(0.28 \mathrm{~g}$, $1.7 \mathrm{mmol}$ ) were dissolved in $10 \mathrm{~mL}$ deionized water and $40 \mathrm{~mL} \mathrm{~N}, N$-dimethylformamide (DMF), respectively. After complete dissolution, these two solutions were ultrasonically mixed for $30 \mathrm{~min}$. After that, $\mathrm{Fe}_{3} \mathrm{O}_{4}-\mathrm{COOH}(0.1 \mathrm{~g}, 0.4 \mathrm{mmol})$ was added to the solution, and the particles were evenly dispersed by ultrasonication for another $10 \mathrm{~min}$. The solution was then transferred to the Polytetrafluoroethylene (PTFE) reactor and reacted at $150{ }^{\circ} \mathrm{C}$ for $24 \mathrm{~h}$. At the end of the reaction, the solution was activated with $\mathrm{N}, \mathrm{N}$-dimethylformamide for $8 \mathrm{~h}$ at $130^{\circ} \mathrm{C}$ After activation, the product was separated by an external magnetic field and washed three times with methanol. Then, the solid was dried at $80^{\circ} \mathrm{C}$ for $12 \mathrm{~h}$, and the magnetic MOF with core/shell particles $\left(\mathrm{Fe}_{3} \mathrm{O}_{4} @ \mathrm{MIL}-53(\mathrm{Al})\right)$ was obtained.

\subsection{Adsorption Experiments}

In the adsorption experiments, $\mathrm{BPA}, \mathrm{TC}, \mathrm{CR}$, and $\mathrm{MB}$ were dissolved in deionized water to make solutions with different concentrations $\left(20-150 \mathrm{mg} \mathrm{L}^{-1}\right)$. The adsorbents were added to $20 \mathrm{~mL}$ of a $100 \mathrm{mg} \mathrm{L}^{-1}$ dye solution, and then shaken at $500 \mathrm{rpm}$ in a constant-temperature oscillator. The ionic strength was modulated by adding different masses of sodium chloride. The $\mathrm{pH}$ values (5.0-11.0) were adjusted by $0.1 \mathrm{M} \mathrm{HCl}$ and $0.1 \mathrm{M} \mathrm{NaOH}$ solutions. The supernatant was measured by a UV-Vis spectrophotometer. All parallel experiments were performed in triplicate to ensure accuracy, and the average results were employed for further data analysis. The removal efficiency of dyes and the adsorption amount were calculated by the following formula:

$$
\begin{gathered}
\text { Dye removal efficiency }(\%)=\frac{M_{0}-M}{M_{0}} \\
Q_{e}=\frac{\left(C_{0}-C_{e}\right) V}{m}
\end{gathered}
$$

where $M_{0}(\mathrm{~g})$ is the initial mass of the dye, and $M(\mathrm{~g})$ is the mass of the dye after adsorption; $Q_{\mathrm{e}}\left(\mathrm{mg} \mathrm{g}^{-1}\right)$ is the equilibrium dye adsorption amount; $V(\mathrm{~mL})$ is the volume of the dye solution; $m(\mathrm{mg})$ is the adsorbent mass.

Based on adsorption experiments, we discuss the adsorption kinetics models, adsorption isotherm and adsorption thermodynamics to explore the possible adsorption mechanism between adsorbent and dyes. A detailed calculation process was listed in the Supplementary Materials.

\subsection{Regeneration Experiments}

After each adsorption, $\mathrm{Fe}_{3} \mathrm{O}_{4} @ \mathrm{MIL}-53(\mathrm{Al})$ was alternately eluted by $0.1 \mathrm{M} \mathrm{NaOH}$ and ethanol solution until no dye could be detected in the supernatant. The regenerated $\mathrm{Fe}_{3} \mathrm{O}_{4} @ \mathrm{MIL}-53(\mathrm{Al})$ was dried in a vacuum oven at $60^{\circ} \mathrm{C}$ overnight. 


\section{Results and Discussion}

\subsection{Characterization of $\mathrm{Fe}_{3} \mathrm{O}_{4} @ M I L-53(\mathrm{Al})$}

Figure 1a shows the XRD patterns of $\mathrm{Fe}_{3} \mathrm{O}_{4}-\mathrm{COOH}$, MIL-53(Al), and $\mathrm{Fe}_{3} \mathrm{O}_{4} @ \mathrm{MIL}-$ 53(Al). Both $\mathrm{Fe}_{3} \mathrm{O}_{4}-\mathrm{COOH}$ and $\mathrm{Fe}_{3} \mathrm{O}_{4} @ \mathrm{MIL}-53(\mathrm{Al})$ showed characteristic diffraction peaks of $\mathrm{Fe}$ at $35.5^{\circ}$, indicating the existence of $\mathrm{Fe}$ in $\mathrm{Fe}_{3} \mathrm{O}_{4} @ \mathrm{MIL}-53(\mathrm{Al})$. Meanwhile, MIL-53 (Al) peaks at $8.9^{\circ}, 10.15^{\circ}, 15.3^{\circ}, 18.38^{\circ}$ and $25.5^{\circ}$, were consistent with those in the literature [30], and confirming that the product was MIL-53 (Al). The XRD pattern of $\mathrm{Fe}_{3} \mathrm{O}_{4} @ \mathrm{MIL}-53(\mathrm{Al})$ has a diffraction peak at $8.9^{\circ}, 10.15^{\circ}, 15.3^{\circ}, 18.38^{\circ}, 25.5^{\circ}$, and $35.5^{\circ}$, which includes the characteristic peak of $\mathrm{Fe}$, and also the characteristic peaks of MIL-53(Al), indicating that $\mathrm{Fe}_{3} \mathrm{O}_{4} @$ MIL-53(Al) was composed of $\mathrm{Fe}_{3} \mathrm{O}_{4}$ and MIL-53(Al).
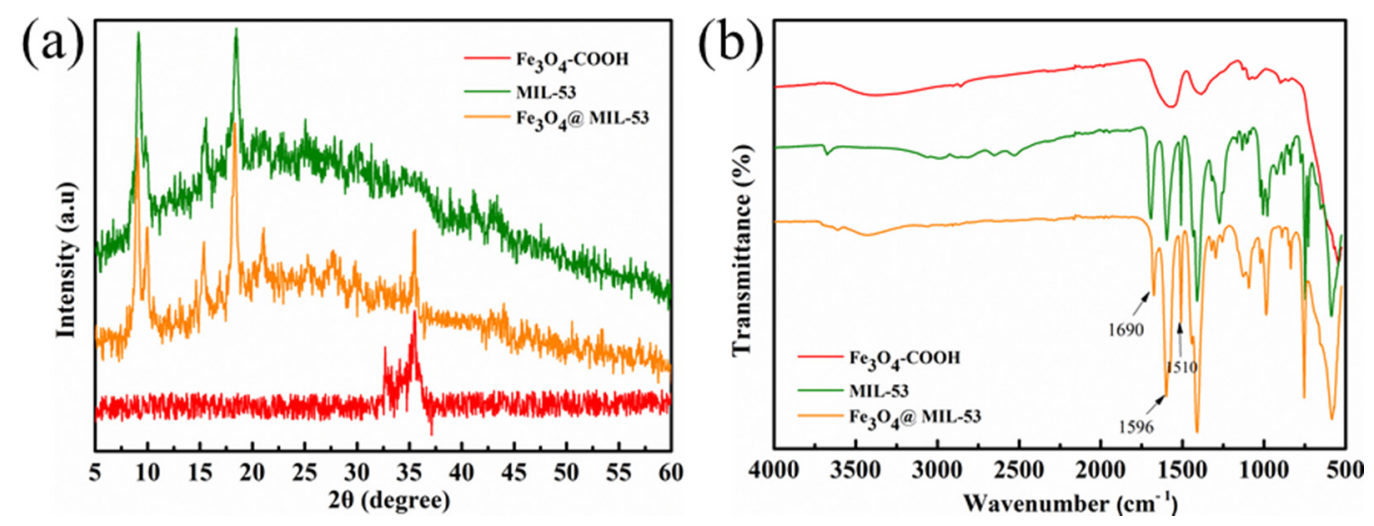

Figure 1. (a) XRD pattern of $\mathrm{Fe}_{3} \mathrm{O}_{4}-\mathrm{COOH}$, MIL-53(Al) and $\mathrm{Fe}_{3} \mathrm{O}_{4} @ M I L-53(\mathrm{Al})$; (b) FT-IR spectra of $\mathrm{Fe}_{3} \mathrm{O}_{4}-\mathrm{COOH}$, MIL53(Al) and $\mathrm{Fe}_{3} \mathrm{O}_{4} @ \mathrm{MIL}-53(\mathrm{Al})$.

The infrared spectra of $\mathrm{Fe}_{3} \mathrm{O}_{4}-\mathrm{COOH}$, MIL-53(Al), and $\mathrm{Fe}_{3} \mathrm{O}_{4} @ \mathrm{MIL}-53(\mathrm{Al})$ are shown in Figure 1b. In the spectra of $\mathrm{Fe}_{3} \mathrm{O}_{4}-\mathrm{COOH}$ and $\mathrm{Fe}_{3} \mathrm{O}_{4} @ \mathrm{MIL}-53(\mathrm{Al})$, the peak at $553 \mathrm{~cm}^{-1}$ was related to the Fe-O vibrational bond. The peak of MIL-53(Al) and $\mathrm{Fe}_{3} \mathrm{O}_{4} @ \mathrm{MIL}-53(\mathrm{Al})$ at $1000-1100 \mathrm{~cm}^{-1}$ was due to the presence of Al-O bonds, and the absorption peaks at 1596 and $1510 \mathrm{~cm}^{-1}$ were due to the asymmetric stretching vibration of $\mathrm{C}-\mathrm{O}$. The absorption peak at $1690 \mathrm{~cm}^{-1}$ was related to the stretching vibration of $-\mathrm{C}=\mathrm{O}$ [31]. The $\mathrm{Fe}_{3} \mathrm{O}_{4} @$ MIL-53(Al) particles synthesized from MIL-53(Al) and $\mathrm{Fe}_{3} \mathrm{O}_{4}-\mathrm{COOH}$ contained absorption peaks at $553 \mathrm{~cm}^{-1}$, and also retained characteristic peaks at 1690,1596, and $1510 \mathrm{~cm}^{-1}$, indicating that the addition of MIL-53(Al) enriched the functional groups of the composite particles $\mathrm{Fe}_{3} \mathrm{O}_{4} @ \mathrm{MIL}-53(\mathrm{Al})$, thus proving the successful preparation of the $\mathrm{Fe}_{3} \mathrm{O}_{4} @ \mathrm{MIL}-53(\mathrm{Al})$ composite particles.

The morphology, structure, and size of $\mathrm{Fe}_{3} \mathrm{O}_{4} @ \mathrm{MIL}-53(\mathrm{Al})$ are shown in Figure 2. In the SEM image, MIL-53(Al) appears as thick and short rods stacked (200 $\mathrm{nm}$ in length and $20 \mathrm{~nm}$ in diameter) in Figure 2a. After the addition of $\mathrm{Fe}_{3} \mathrm{O}_{4}$ particles, we still observed much the short rod-like morphology and few spheres ( $c a 300 \mathrm{~nm}$ in diameter, the red dotted line part) in Figure $2 \mathrm{~b}$. These exposed spherical spheres were $\mathrm{Fe}_{3} \mathrm{O}_{4}$ that were not completely covered by MIL-53(Al). On the one hand, this proves the existence of $\mathrm{Fe}_{3} \mathrm{O}_{4}$ in the $\mathrm{Fe}_{3} \mathrm{O}_{4} @ \mathrm{MIL}-53(\mathrm{Al})$ composite particles; on the other hand, this also indicates that most $\mathrm{Fe}_{3} \mathrm{O}_{4}$ was completely covered by MIL-53(Al) and lies inside the $\mathrm{Fe}_{3} \mathrm{O}_{4} @ \mathrm{MIL}-$ 53(Al) composite, which is not easily observed. The same conclusion was obtained by TEM in Figure 2c,d. From the TEM image, the stacked MIL-53 (Al) are baculiform and pure particles before adding $\mathrm{Fe}_{3} \mathrm{O}_{4}$. After complexing with $\mathrm{Fe}_{3} \mathrm{O}_{4}$, the $\mathrm{Fe}_{3} \mathrm{O}_{4}$ particles are black and spherical, distributing inside the MIL-53 (Al) to form composite particles. The black particles range from 100 to $300 \mathrm{~nm}$ in diameter and most of them are completely surrounded by MIL-53 (Al). 
(a)

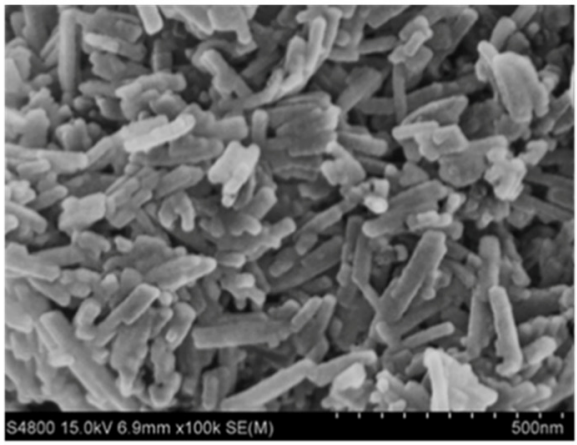

(c)

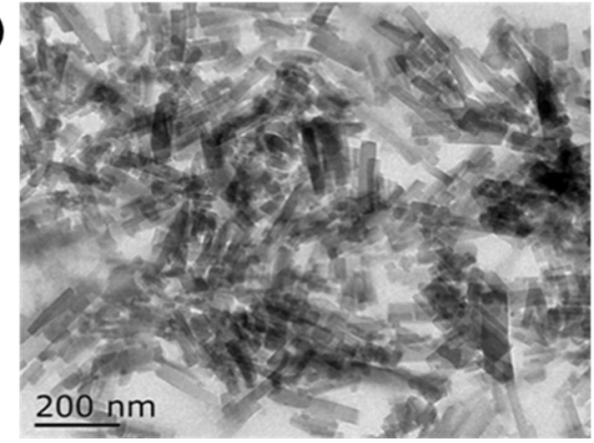

(b)

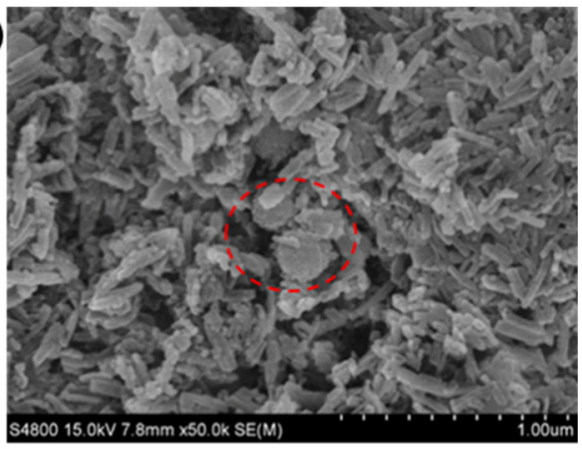

(d)

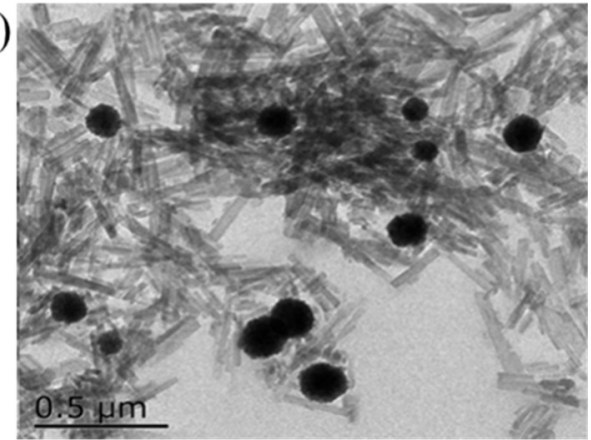

Figure 2. SEM images of (a) MIL-53(Al), (b) $\mathrm{Fe}_{3} \mathrm{O}_{4} @$ MIL-53(Al); TEM images of (c) MIL-53(Al) and (d) $\mathrm{Fe}_{3} \mathrm{O}_{4} @ M I L-53(\mathrm{Al})$.

The magnetic performance was measured by magnetic hysteresis loops with varying magnetic fields (Figure 3). $\mathrm{Fe}_{3} \mathrm{O}_{4}-\mathrm{COOH}$ and $\mathrm{Fe}_{3} \mathrm{O}_{4} @ \mathrm{MIL}-53(\mathrm{Al})$ are both magnetic with magnetic saturation strengths of $61.12 \mathrm{emu} / \mathrm{g}$ and $10.61 \mathrm{emu} / \mathrm{g}$, respectively. Compared with the pure $\mathrm{Fe}_{3} \mathrm{O}_{4}-\mathrm{COOH}$ particles, the magnetism of composite particle $\mathrm{Fe}_{3} \mathrm{O}_{4} @$ MIL$53(\mathrm{Al})$ becomes weaker. Because MIL-53(Al) is a non-magnetic material, the introduction of non-magnetic materials weakened the magnetic properties of the composite. Although the magnetism of $\mathrm{Fe}_{3} \mathrm{O}_{4} @ \mathrm{MIL}-53(\mathrm{Al})$ is inferior to pure $\mathrm{Fe}_{3} \mathrm{O}_{4}-\mathrm{COOH}$, the $\mathrm{Fe}_{3} \mathrm{O}_{4} @$ MIL53(Al) still is sedimentation and separate rapidly with an external magnetic field, which is convenient for recycling.

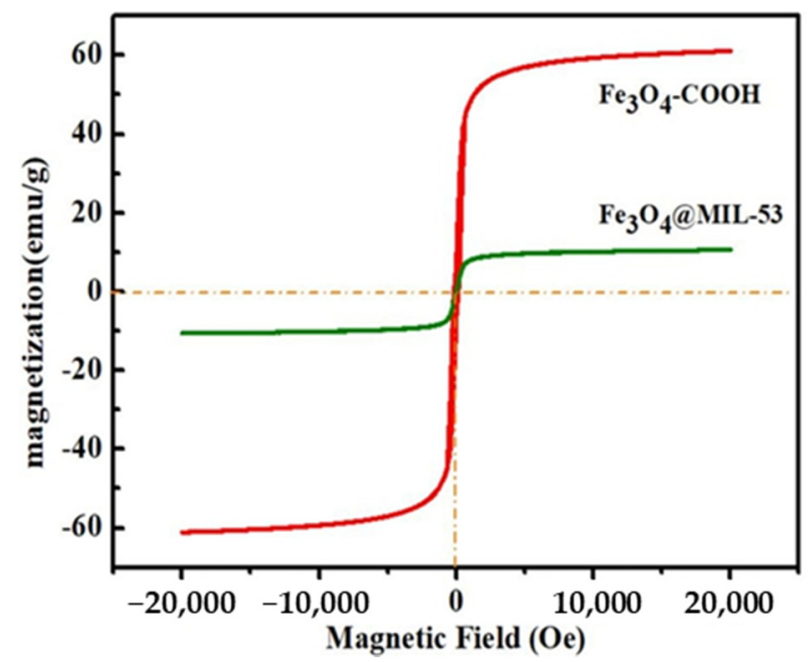

Figure 3. Vibrating sample magnetometry image of $\mathrm{Fe}_{3} \mathrm{O}_{4}-\mathrm{COOH}$ and $\mathrm{Fe}_{3} \mathrm{O}_{4} @ M I L-53(\mathrm{Al})$. 


\subsection{Adsorption of $B P A, T C, C R$, and $M B$}

\subsubsection{Influence of Adsorbent Amounts}

The adsorption capacity of bisphenol A, tetracycline, congo red, and methylene blue all decreased upon increasing the $\mathrm{Fe}_{3} \mathrm{O}_{4} @ \mathrm{MIL}-53(\mathrm{Al})$ absorbent amount, which is illustrated in Figure $4 \mathrm{a}$. In the beginning, the adsorbents can provide plentiful and accessible unsaturated active sites at the low amount adsorbents. However, with the increase of the dosage of adsorbent, there were more adsorption sites that are not occupied for the adsorption process, leading to a reduction in the adsorption capacity. Therefore, in subsequent experiments, the adsorbent mass used for bisphenol A and tetracycline was $0.6 \mathrm{~g} / \mathrm{L}$ and $0.75 \mathrm{~g} / \mathrm{L}$, respectively, and the addition amounts of Congo red and methylene blue were $0.2 \mathrm{~g} / \mathrm{L}$ and $0.5 \mathrm{~g} / \mathrm{L}$, respectively.

(a)

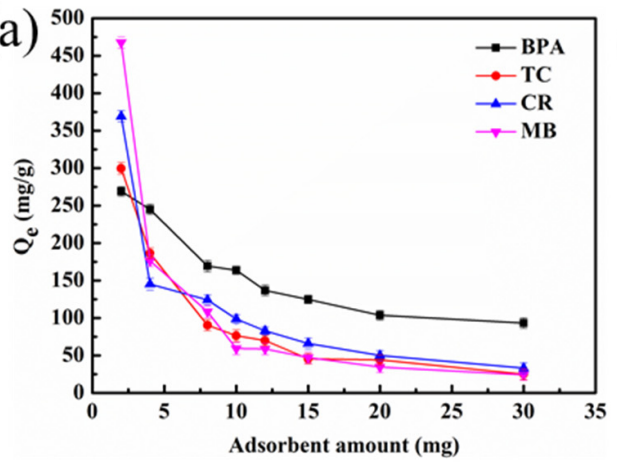

(c)

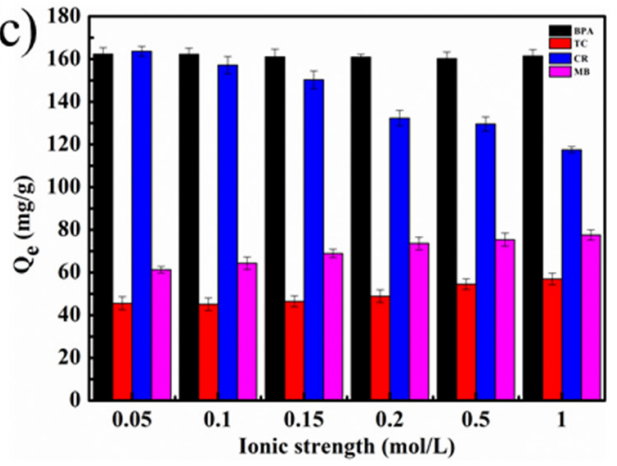

(b)

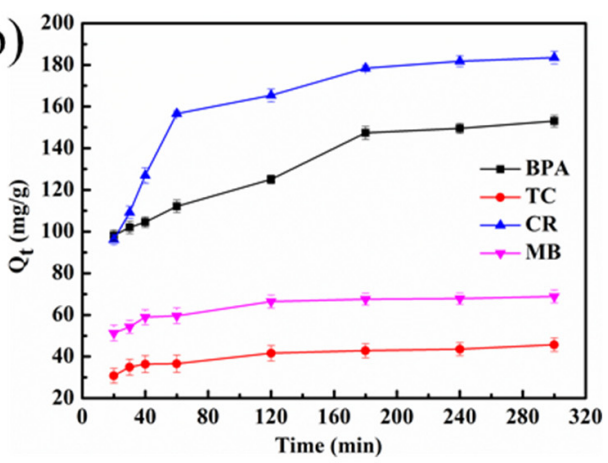

(d)

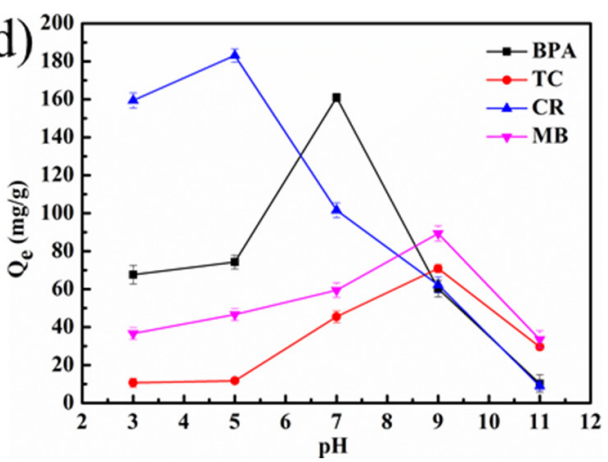

Figure 4. (a) influence of adsorbent amounts on BPA, TC, CR, and MB; (b) influence of time on BPA, $\mathrm{TC}, \mathrm{CR}$, and MB; and (c) influence of ionic strength on BPA, TC, CR, and MB; (d) Influence of $\mathrm{pH}$ on $\mathrm{BPA}, \mathrm{TC}, \mathrm{CR}$, and MB. Those error bars are standard deviations. The materials were independently prepared to repeat the same experiment at least three times to ensure the accuracy of the data.

\subsubsection{Influence of Adsorption Time}

In this section, the effect of adsorption time was investigated from 20 to $300 \mathrm{~min}$. According to Figure $4 b$, upon extending the adsorption time, the adsorption capacity of bisphenol A and Congo red both increased. At 0-180 min, the adsorption capacity of these two pollutants increased rapidly. From 180 to $300 \mathrm{~min}$, the adsorption capacity of bisphenol A and Congo red did not increase significantly upon the increasing time, so $180 \mathrm{~min}$ was the adsorption equilibrium time of bisphenol $\mathrm{A}$ and Congo red; however, the adsorption capacity of tetracycline and methylene blue did not change significantly with time after $120 \mathrm{~min}$, so $120 \mathrm{~min}$ was the optimal adsorption equilibrium time for tetracycline and methylene blue.

Although the adsorption equilibrium time of different pollutants was different, the adsorption process was generally divided into two stages. The first stage is the rapid adsorption stage, in which the adsorption amount of pollutants increased significantly with time. The second stage is the slow adsorption stage. Even if the adsorption time increases, the adsorption amount of pollutants increased slowly, and the final equilibrium adsorption amount did not change. This is because, at the initial stage of adsorption, a large number 
of holes and adsorption sites on the surface and inside of the adsorbent can be occupied by contaminant molecules; however, upon extending the time, pollutant molecules occupied the pores and adsorption sites, and the available vacancy sites became less and less, leading to a slower adsorption rate before finally reaching an adsorption equilibrium [32].

\subsubsection{Influence of Ionic Strength}

The influence of ionic strength on the adsorption efficiency was investigated by varying the $\mathrm{NaCl}$ concentration from 0.01 to $1.0 \mathrm{M}$. Figure $4 \mathrm{c}$ shows that different pollutants are affected by the ion intensity to different degrees. Among them, bisphenol A was less affected by ions. Upon changing $\mathrm{NaCl}$ concentration, the adsorption amount of bisphenol A changed only slightly. For Congo red, the effect of ionic strength was negative and the adsorption capacity decreased upon increasing the ionic strength. When the $\mathrm{NaCl}$ concentration increased from 0.05 to $1 \mathrm{M}$, the adsorption capacity of Congo red decreased from $163 \mathrm{mg} / \mathrm{g}$ to $117 \mathrm{mg} / \mathrm{g}$. Obviously, the higher the ionic strength, the more unfavorable the adsorption of Congo red by $\mathrm{Fe}_{3} \mathrm{O}_{4} @ \mathrm{MIL}-53(\mathrm{Al})$. For $\mathrm{Fe}_{3} \mathrm{O}_{4} @ \mathrm{MIL}-53(\mathrm{Al})$ the adsorption of tetracycline and methylene blue, the effect of ionic strength was positive. In other words, upon increasing the ionic strength, the adsorption capacity of tetracycline and methylene blue increased, indicating that ionic strength was conducive to the adsorption of tetracycline and methylene blue by $\mathrm{Fe}_{3} \mathrm{O}_{4} @ \mathrm{MIL}-53(\mathrm{Al})$. When more ions were present in the solution, the adsorption capacity of tetracycline and methylene blue was more favorable.

The different effects of ion strength on adsorption are due to the different effects of ions in different adsorption systems. Generally speaking, the effect of ionic strength on adsorption is mainly reflected in two aspects; the salting-out effect and the competition effect [33-36]. Salting out was dominant in the $\mathrm{Fe}_{3} \mathrm{O}_{4} @ \mathrm{MIL}-53(\mathrm{Al})$ adsorption system for tetracycline and methylene blue, because the adsorption capacities increased on increasing the ionic strength. The adsorption process of $\mathrm{Fe}_{3} \mathrm{O}_{4} @ \mathrm{MIL}-53(\mathrm{Al})$ was dominated by competition because the adsorption amount of Congo red decreased after increasing the ionic strength; however, during the adsorption of bisphenol $\mathrm{A}$, the salting-out effort and competition canceled each other out, or their two influences were relatively weak, and ions in the solution simply did not affect adsorption. In this case, the adsorption capacity of $\mathrm{Fe}_{3} \mathrm{O}_{4} @ \mathrm{MIL}-53(\mathrm{Al})$ for bisphenol A did not change significantly upon changing the ion strength.

\subsubsection{Influence of $\mathrm{pH}$}

The $\mathrm{pH}$ of the solution can greatly influence the adsorption of dyes. In this work, the influence of sample $\mathrm{pH}$ on the removal efficiency was investigated in the $\mathrm{pH}$ range of 5-11, and the results are illustrated in Figure $4 \mathrm{~d}$. The adsorption capacity of bisphenol A reached its maximum at $\mathrm{pH}=7$. Upon increasing the alkalinity of the solution, the adsorption capacity of bisphenol A decreased sharply. This is because at $\mathrm{pH}>9$, bisphenol A was ionized into the monovalent anion $\mathrm{HBPA}^{-}$and bivalent anion $\mathrm{BPA}^{2-}$, which electrostatically rejected the adsorbent due to the negative surface charge, making the adsorption amount lower. When the solution was acidic, a large number of $\mathrm{H}^{+}$and positively-charged adsorbents on the surface electrostatically repelled bisphenol A, so the adsorption capacity of bisphenol A reached the maximum when the $\mathrm{pH}$ was 7 . However, Congo red is favorable for adsorption under acidic conditions. When the $\mathrm{pH}$ was 3-5, the adsorption capacity of $\mathrm{Fe}_{3} \mathrm{O}_{4} @ \mathrm{MIL}-53(\mathrm{Al})$ for Congo red increased upon increasing the $\mathrm{pH}$. When the $\mathrm{pH}$ was between 5 and 11, the adsorption capacity of Congo red decreased upon increasing the $\mathrm{pH}$, so the adsorption effect of Congo red was the best at $\mathrm{pH}=5$. This is because when $\mathrm{pH}<6$, there is an electrostatic attraction between the anionic dye Congo red and the positively charged adsorbent, which increases the adsorption capacity. However, when the $\mathrm{pH}>6$, the structure of Congo red changes and the surface becomes negatively charged. Upon increasing the $\mathrm{pH}$, the charge on the surface of the adsorbent becomes negative, and the electrostatic repulsion reduces the amount of adsorption. 
However, the adsorption capacity of $\mathrm{Fe}_{3} \mathrm{O}_{4} @ \mathrm{MIL}-53(\mathrm{Al})$ for tetracycline and methylene blue increased when the $\mathrm{pH}$ was increased and reached the maximum at $\mathrm{pH}=9$. When the $\mathrm{pH}$ of the solution was further increased to $\mathrm{pH}=11$, the adsorption capacity of $\mathrm{Fe}_{3} \mathrm{O}_{4} @ \mathrm{MIL}-$ 53(Al) for tetracycline and methylene blue was extremely low. Under acidic conditions, both tetracycline $\left(\mathrm{TC}^{+}\right)$and methylene blue exist as cations, which are electrostatically repelled by the positively charged adsorbent surface, resulting in a low adsorption capacity. When $\mathrm{pH}=11$, tetracycline and methylene blue are ionized as anion $\mathrm{TC}^{2-}$, and are electrostatically repelled by the negatively charged surface, resulting in a low adsorption capacity. When $\mathrm{pH}=9$, a similar situation would be expected, but that was not observed in the experimental results. This indicates that the primary interaction between the adsorbent and the adsorbent are not charges, but rather $\mathrm{H}$ bonding and $\pi-\pi$ conjugation; therefore, the adsorption effect of Bisphenol A was best when $\mathrm{pH}=7$. The adsorption effect of Congo red was the best when $\mathrm{pH}=5$. The adsorption of both tetracycline and methylene blue was most favorable at $\mathrm{pH}=9$.

\subsection{Adsorption Kinetics}

Adsorption kinetics are used to elucidate the adsorption behaviors including mass transfer, chemical reaction, and the rate-determining step of adsorption. In this section, the pseudo-first-order, pseudo-second-order, and intraparticle diffusion models were applied to the experimental data.

The linear regression curves of the three models for adsorbing BPA, TC, CR, and MB are presented in Figure $5 \mathrm{a}-\mathrm{C}$, and all model parameters are shown in Table 2. The adsorption data of the prepared adsorbents on bisphenol A, tetracycline, Congo red, and methylene blue were better fitted by the quasi-second-order model, because the fitting coefficients were all above 0.98 , and a good linear fit was obtained. The secondary dynamic adsorption equilibrium amounts of bisphenol A (BPA), tetracycline, Congo red, and methylene blue were calculated to be $162.6,46.1,200.0$, and $69.9 \mathrm{mg} / \mathrm{g}$. These were not far from the experimental value, indicating that the adsorption kinetics of these four pollutions follow the second-order kinetics model and process via chemical adsorption. The adsorption capacity of $\mathrm{Fe}_{3} \mathrm{O}_{4} @$ MIL-53(Al) is associated with its number of available active sites [37,38]. In addition to the poor quasi-first-order kinetic fitting coefficient of Congo red, the $R^{2}$ values of bisphenol $\mathrm{A}$, tetracycline and methylene blue were all above 0.9 , and the fitting coefficient was also good, indicating that bisphenol A, tetracycline, and methylene blue underwent physical adsorption on $\mathrm{Fe}_{3} \mathrm{O}_{4} @$ MIL-53(Al).

As can be seen from $Q t$ in Figure $5 c$, the intramolecular diffusion models of bisphenol A, tetracycline, Congo red and methylene blue do not pass through the origin, indicating that during adsorption of these four pollutants, internal diffusion is not the only step that controls adsorption, and there are two or more diffusion mechanisms that affect adsorption. The line is divided into a first stage $\left(K_{\mathrm{i} 1}\right)$ and second stage $\left(K_{\mathrm{i} 2}\right)$. The first stage involves the migration of pollutant molecules from the solution to the outer surface of the adsorbent. During the second stage, the pollutant molecules diffuse to the adsorbent pores. All four pollutants have high $R^{2}$ in the second stage, indicating that the diffusion of pollutant molecules into the adsorbent pores is the rate-controlling step of these four pollutants [39].
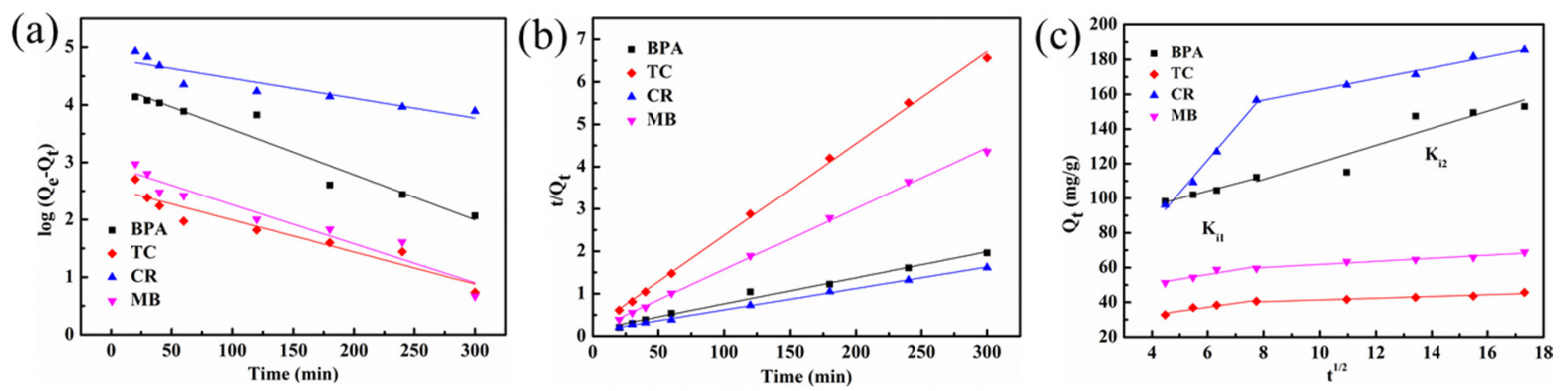

Figure 5. Fit of kinetic data to (a) the pseudo-first-order model, (b) the pseudo-second-order model, and (c) the intraparticle diffusion model on BPA, TC, CR, and MB. 
Table 2. Parameters of Pseudo-First-Order, Pseudo-Second-Order, and Intraparticle Diffusion Models.

\begin{tabular}{|c|c|c|c|c|c|}
\hline \multirow[t]{2}{*}{ Kinetics } & \multirow[t]{2}{*}{ Parameters } & \multicolumn{4}{|c|}{ Dyes } \\
\hline & & BPA & TC & CR & MB \\
\hline \multirow{4}{*}{ Pseudo-Second-Order Model } & $Q_{\mathrm{cal}}{ }^{\mathrm{a}}(\mathrm{mg} / \mathrm{g})$ & 162.6 & 46.1 & 200.0 & 69.9 \\
\hline & $Q_{\exp }{ }^{b}(\mathrm{mg} / \mathrm{g})$ & 160.9 & 47.8 & 234.4 & 70.8 \\
\hline & $k_{2}(\mathrm{~g} / \mathrm{mg} / \mathrm{min})$ & $2.62 \times 10^{-4}$ & $2.35 \times 10^{-3}$ & $2.26 \times 10^{-4}$ & $1.54 \times 10^{-3}$ \\
\hline & $R^{2}$ & 0.9897 & 0.9984 & 0.9988 & 0.9986 \\
\hline \multirow{3}{*}{ Pseudo-First-Order Model } & $Q_{\mathrm{cal}}{ }^{\mathrm{a}}(\mathrm{mg} / \mathrm{g})$ & 78.1 & 12.8 & 122.0 & 18.9 \\
\hline & $k_{1}\left(\min ^{-1}\right)$ & 0.0079 & 0.0055 & 0.0034 & 0.0068 \\
\hline & $R^{2}$ & 0.9332 & 0.9047 & 0.8343 & 0.9236 \\
\hline \multirow{6}{*}{ Intraparticle Diffusion Models } & $k_{\mathrm{i} 1}\left(\mathrm{mg} / \mathrm{g} / \min ^{1 / 2}\right)$ & 2.65 & 2.28 & 18.79 & 1.75 \\
\hline & $C_{1}(\mathrm{mg} / \mathrm{g})$ & 87.9 & 23.5 & 18.8 & 45.2 \\
\hline & $R^{2}$ & 0.8657 & 0.8971 & 0.9801 & 0.8249 \\
\hline & $k_{\mathrm{i} 2}\left(\mathrm{mg} / \mathrm{g} / \min ^{1 / 2}\right)$ & 1.43 & 0.50 & 3.11 & 0.82 \\
\hline & $\mathrm{C}_{2}(\mathrm{mg} / \mathrm{g})$ & 127.9 & 36.4 & 131.7 & 53.9 \\
\hline & $R^{2}$ & 0.9329 & 0.9129 & 0.9845 & 0.8599 \\
\hline
\end{tabular}

${ }^{a} Q_{e, e x p}$ is the equilibrium adsorption capacities according to the experimental results. ${ }^{b} Q_{e, c a l}$ is determined by the linear fitting from the kinetic models.

\subsection{Adsorption Isotherms}

The adsorption isotherm is important for investigating the adsorption type and strength between the adsorbents and the target compounds in the adsorption batch system. As can be seen from Figure 6 and Table 3, the Langmuir linear fitting coefficients of bisphenol A, tetracycline, and CR were higher than that of the Freundlich model, indicating that the Langmuir model better described the adsorption process and that $\mathrm{Fe}_{3} \mathrm{O}_{4} @ \mathrm{MIL}-53(\mathrm{Al})$ adsorbed bisphenol A, tetracycline, and CR in a homogeneous and single-molecular layer process. The experimental data of the adsorption of methylene blue by $\mathrm{Fe}_{3} \mathrm{O}_{4} @ \mathrm{MIL}-53(\mathrm{Al})$ was better fitted by the Freundlich isotherm model $\left(R^{2}>0.99\right)$, indicating that $\mathrm{Fe}_{3} \mathrm{O}_{4} @ \mathrm{MIL}-$ 53(Al) adsorbed methylene blue via heterogeneous, multi-molecular layer adsorption. According to the Freundlich isotherm model, the $1 / n$ values of the four pollutants were all less than 1, indicating that $\mathrm{Fe}_{3} \mathrm{O}_{4} @ \mathrm{MIL}-53(\mathrm{Al})$ was favorable and easily adsorbed bisphenol A, tetracycline, CR, and MB [40]. A Langmuir model was used to calculate the maximum adsorption capacity of $\mathrm{Fe}_{3} \mathrm{O}_{4} @ \mathrm{MIL}-53(\mathrm{Al})$ to bisphenol A, tetracycline, Congo red, and methylene blue, which were respectively $205.00,78.93,179.53$, and $148.81 \mathrm{mg} / \mathrm{g}$, showing an excellent adsorption effect.
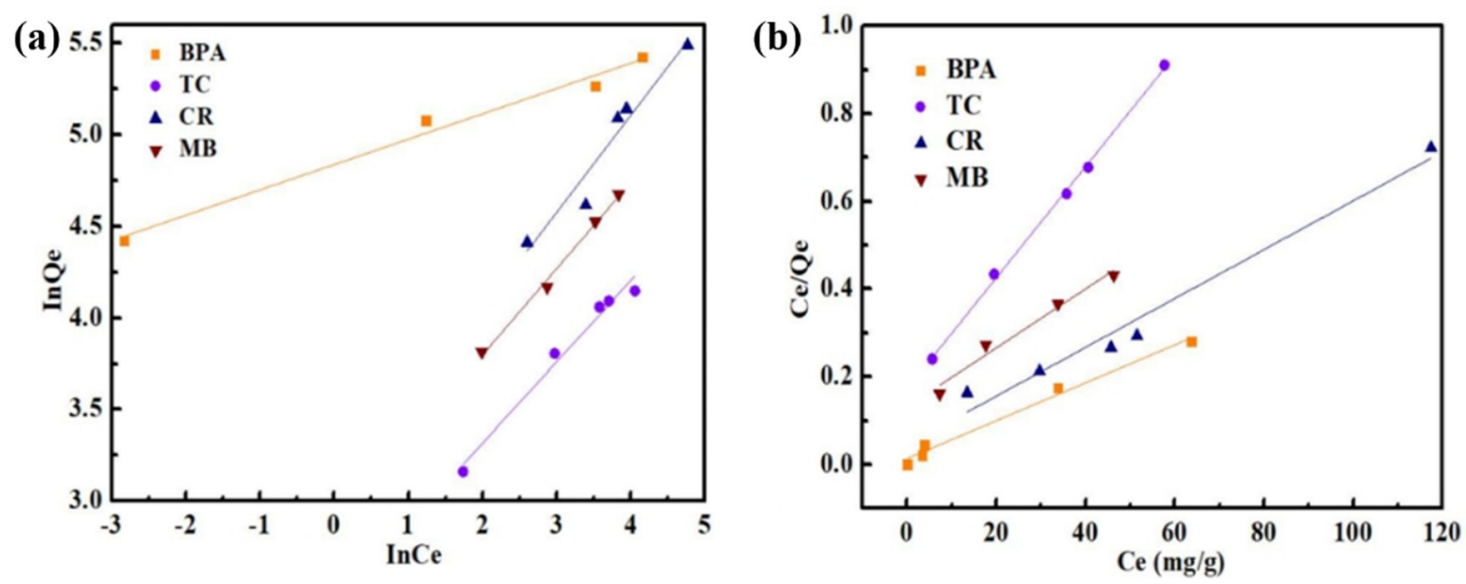

Figure 6. Adsorption isotherm curves of BPA, TC, CR, and $\mathrm{MB}$ on $\mathrm{Fe}_{3} \mathrm{O}_{4} @ \mathrm{MIL}-53(\mathrm{Al})$. (a) Freundlich model; (b) Langmuir model. 
Table 3. Isotherm Parameters of $\mathrm{Fe}_{3} \mathrm{O}_{4} @ \mathrm{MIL}-53(\mathrm{Al})$ for BPA, TC, CR, and MB Adsorption.

\begin{tabular}{ccccccc}
\hline Dyes & \multicolumn{3}{c}{ Langmuir Model } & \multicolumn{3}{c}{ Freundlich Model } \\
\hline & $\boldsymbol{Q}_{\max }(\mathbf{m g} \mathbf{g})$ & $\boldsymbol{K}_{\mathbf{L}} \mathbf{( L / m g )}$ & $\boldsymbol{R}^{\mathbf{2}}$ & $\mathbf{1} / \boldsymbol{n}$ & $\boldsymbol{K}_{\mathbf{F}}$ & $\boldsymbol{R}^{\mathbf{2}}$ \\
\hline BPA & 205.0 & 0.3077 & 0.9835 & 0.1380 & 126.2 & 0.9758 \\
TC & 78.9 & 0.0735 & 0.9978 & 0.4441 & 11.4 & 0.9726 \\
CR & 179.5 & 0.1253 & 0.9670 & 0.5303 & 19.8 & 0.9262 \\
MB & 148.8 & 0.0511 & 0.9611 & 0.4711 & 17.4 & 0.9924 \\
\hline
\end{tabular}

The comparison of the adsorbent developed in this work with previously reported adsorbents for the removal of BPA, TC, CR, and MB is summarized in Table 4. Although $\mathrm{Fe}_{3} \mathrm{O}_{4} @ \mathrm{MIL}-53(\mathrm{Al})$ has a lower adsorption capacity than pure MIL-53(Al) or MIL-53(Fe), the functionalization with magnetic particles endows materials the ability which can be easily separated by a magnetic field. The adsorption capacities for the targeted pollutants can be compared to some reported adsorbents, verifying it to act as a potential purifying agent for removing cationic dyes from wastewater.

Table 4. Comparison of the $\mathrm{Fe}_{3} \mathrm{O}_{4} @ \mathrm{MIL}-53(\mathrm{Al})$ uptake with some previous works.

\begin{tabular}{cccc}
\hline Adsorbent & $Q_{\max }(\mathbf{m g} / \mathrm{g})$ & Target Pollutant & Reference \\
\hline & $160.9 \mathrm{mg} / \mathrm{g}$ & BPA & \\
$\mathrm{Fe}_{3} \mathrm{O}_{4} @$ MIL-53(Al) & $47.8 \mathrm{mg} / \mathrm{g}$ & TC & This Work \\
& $234.4 \mathrm{mg} / \mathrm{g}$ & $\mathrm{CR}$ & \\
\hline MIL-53(Al) & $70.8 \mathrm{mg} / \mathrm{g}$ & $\mathrm{MB}$ & {$[31]$} \\
\hline MIL-53(Fe) & $329.2 \pm 16.5 \mathrm{mg} / \mathrm{g}$ & BPA & {$[41]$} \\
& $247.7 \mathrm{mg} / \mathrm{g}$ & $\mathrm{TC}$ & {$[42]$} \\
\hline MIL-101-NH & $1482 \mathrm{mg} / \mathrm{g}$ & $\mathrm{CR}$ & {$[43]$} \\
\hline CWs Ben-Rm-Ps ceramsite & Less than $100 \mathrm{mg} / \mathrm{g}$ & BPA & {$[44]$} \\
\hline CDGO nanosheets & $2.56 \mathrm{mg} / \mathrm{g}$ & TC & {$[45]$} \\
\hline HP- $\beta-C D$ & $23.1 \mathrm{mg} / \mathrm{g}$ & BPA & {$[46]$} \\
\hline
\end{tabular}

\subsection{Adsorption Thermodynamics}

In order to further explore the type of adsorption of bisphenol A (BPA), tetracycline, Congo red, and methylene blue adsorption by $\mathrm{Fe}_{3} \mathrm{O}_{4} @ \mathrm{MIL}-53(\mathrm{Al})$ and explore the possible adsorption mechanism, the adsorption enthalpy change $\left(\Delta H^{\circ}\right)$, the Gibbs free energy change $\left(\Delta G^{\circ}\right)$, and entropy $\left(\Delta S^{\circ}\right)$ were calculated (calculation process in the Supplementary Materials), and the results are listed in Table 5.

In this system, $\Delta H^{\circ}>0$ indicates that the removal efficiencies of the dyes increase with an increase in temperature, and the adsorption process is an endothermic process. According to a previous report, adsorption is physical adsorption when $\Delta G^{\circ}$ ranges from -20 to $0 \mathrm{~kJ} \mathrm{~mol}^{-1}$. When the $\Delta G^{\circ}$ value ranges from -400 to $-80 \mathrm{~kJ} \mathrm{~mol}^{-1}$, adsorption proceeds via chemical adsorption [47].

Table 5 shows that $\Delta H^{\circ}$ for the adsorption of tetracycline, methylene blue, and Congo red by $\mathrm{Fe}_{3} \mathrm{O}_{4} @ \mathrm{MIL}-53(\mathrm{Al})$ is greater than 0 , and $\Delta G^{\circ}$ is less than 0 , indicating a spontaneous endothermic process. However, for the absorption process of bisphenol $\mathrm{A}, \Delta H^{\circ}$ and $\Delta G^{\circ}$ were less than 0 , which indicates a spontaneous exothermic process. In addition, for bisphenol A, tetracycline, methylene blue, and Congo red, $\left|\Delta H^{\circ}\right|$ is within the range of $0-84 \mathrm{~kJ} / \mathrm{mol}$, and $\Delta G^{\circ}$ is in the range -20 to $0 \mathrm{~kJ} / \mathrm{mol}$, which shows that the adsorption of the four pollutants was mainly physical adsorption. The $\Delta G^{\circ}$ of bisphenol A, tetracycline, methylene blue, and Congo red increased with the temperature, showing that at a higher temperature is beneficial for the adsorption of these pollutants by $\mathrm{Fe}_{3} \mathrm{O}_{4} @ \mathrm{MIL}-53(\mathrm{Al})$. 
Table 5. Thermodynamic Parameters for BPA, TC, CR, and MB Adsorption on $\mathrm{Fe}_{3} \mathrm{O}_{4} @ \mathrm{MIL}-53(\mathrm{Al})$.

\begin{tabular}{ccccc}
\hline Dyes & $\boldsymbol{T}(\mathbf{K})$ & $\Delta \boldsymbol{G}^{\circ} \mathbf{( k J / m o l )}$ & $\boldsymbol{\Delta} \boldsymbol{H}^{\circ} \mathbf{( k J / m o l )}$ & $\left.\boldsymbol{\Delta} \boldsymbol{S}^{\circ} \mathbf{( J / m o l} / \mathbf{K}\right)$ \\
\hline \multirow{3}{*}{ BAP } & 298 & -8.23 & - & - \\
& 308 & -9.04 & -34.1 & -81.5 \\
& 318 & -9.86 & - & - \\
TC & 298 & -2.62 & - & 74.9 \\
& 308 & -3.37 & 19.7 & - \\
\hline & 318 & -4.12 & - & - \\
CR & 298 & -3.67 & - & - \\
& 308 & -6.07 & - & - \\
& 318 & -8.47 & - & 47.9 \\
\hline
\end{tabular}

The entropy change $\left(\Delta S^{\circ}\right)$ is also an important thermodynamic parameter. $\Delta S^{\circ}>0$ indicates an increase in entropy, while $\Delta S^{\circ}<0$ indicates a decrease in entropy during the adsorption system [48]. $\Delta S^{\circ}$ is determined by solute adsorption (degree of freedom, entropy decreasing) and solvent desorption (degree of freedom increase, increase in entropy).

Table 5 shows that the $\Delta S^{\circ}$ for the bisphenol $\mathrm{A}$ is different from the other three pollutants. During bisphenol A adsorption, $\Delta S^{\circ}<0$, which indicates a decrease in entropy reduction and system chaos reduction. In this adsorption process, more solute molecules were adsorbed and the degree of freedom decreased, indicating an entropy-reduction process. The adsorption of the other three pollutants involved an increase in entropy, because more water molecules were desorbed from the surface of $\mathrm{Fe}_{3} \mathrm{O}_{4} @ \mathrm{MIL}-53(\mathrm{Al})$ than the adsorbed amount of these three pollutants. More water molecules were desorbed from the adsorbent surface than adsorbent molecules. During the solvent desorption, an increase in entropy was dominant, which increased the entropy of the system.

Based on $\Delta H^{\circ}, \Delta G^{\circ}$, and $\Delta S^{\circ}$, we concluded that $\mathrm{Fe}_{3} \mathrm{O}_{4} @ \mathrm{MIL}-53(\mathrm{Al})$ adsorbed bisphenol A via a spontaneous, exothermic, and entropy-reduction process, which is physical adsorption; the adsorption of tetracycline, Congo red, and methylene blue was a spontaneous, endothermic and entropy-increasing process, which mainly proceeded via physical adsorption.

\subsection{Adsorption Mechanism}

After researching kinetics, isotherm and thermodynamics, we found that the adsorption of the BPA, TC, CR, and MB was all physical adsorption predominantly, which was related to the pore construction between adsorbents and pollutants. When the channels of MIL-53(Al) are occupied by guest molecules or organic ligands, the MIL-53(Al) will change its structure to possess a unique reversible property according to the adjustment of temperature or guest molecules. This also features the MIL-53(Al), or the "breathing" effect of the framework. Therefore, the $\mathrm{Fe}_{3} \mathrm{O}_{4} @ \mathrm{MIL}-53(\mathrm{Al})$ have superior adsorption performances for different target pollutants. The $\mathrm{Fe}_{3} \mathrm{O}_{4} @ \mathrm{MIL}-53$ (Al) can adjust their construction to adapt to diverse pollutant molecular sizes. Particularly noteworthy is the chemical adsorption which also exists between the BPA, TC, CR, and MB and $\mathrm{Fe}_{3} \mathrm{O}_{4} @ \mathrm{MIL}-53(\mathrm{Al})$. This is due to the $\pi-\pi$ interaction between the benzene ring that is present in both the target pollutant and the adsorbent. Moreover, the hydrogen bonding makes contributions to better adsorption performances.

\section{Conclusions}

In this work, a functionalized MOF with magnetic particles $\left(\mathrm{Fe}_{3} \mathrm{O}_{4} @ \mathrm{MIL}-53(\mathrm{Al})\right)$ was designed and prepared for the removal of four pollutants. The structure and performance of $\mathrm{Fe}_{3} \mathrm{O}_{4} @ M I L-53(\mathrm{Al})$ were characterized by SEM, TEM, FT-IR and XRD. The maximum adsorption capacities for BPA, TC, CR, and MB were determined to be $160.9 \mathrm{mg} / \mathrm{g}, 47.8 \mathrm{mg} / \mathrm{g}$, 
$234.4 \mathrm{mg} / \mathrm{g}$, and $70.8 \mathrm{mg} / \mathrm{g}$, respectively, which are much higher than that of other reported adsorbents. The adsorption of BPA, TC, and CR were well-fitted by the Langmuir adsorption isotherm model, while MB followed the Freundlich model, while the adsorption kinetics data of all pollutants followed the pseudo-second-order kinetics models. The thermodynamic values, including the enthalpy change $\left(\Delta H^{\circ}\right)$, the Gibbs free energy change $\left(\Delta G^{\circ}\right)$, and entropy change $\left(\Delta S^{\circ}\right)$, showed that the adsorption processes were spontaneous and exothermic entropy-reduction for BPA, but spontaneous and endothermic entropyincreasing processes for the others. Moreover, $\mathrm{Fe}_{3} \mathrm{O}_{4} @ \mathrm{MIL}-53(\mathrm{Al})$ can be easily separated by an external magnetic field due to the presence of the $\mathrm{Fe}_{3} \mathrm{O}_{4}$ magnetic particle. All of the results demonstrate that $\mathrm{Fe}_{3} \mathrm{O}_{4} @ \mathrm{MIL}-53(\mathrm{Al})$ is a promising adsorbent for removing dyes from wastewater.

Supplementary Materials: The following are available online at https:/ /www.mdpi.com/article/10 .3390/nano11081917/s1. Supplementary Materials: 1. Adsorption model.

Author Contributions: Conceptualization, G.Z., Z.S., G.L., Y.Z., H.G. and W.J.; Funding acquisition, G.Z. and H.G.; Investigation, G.H.; Methodology, R.W. and G.L.; Project administration, W.J.; Resources, G.H. and H.G.; Software, R.W.; Supervision, G.H. and Y.Z.; Validation, Z.S.; Visualization, R.W.; Writing—original draft, Z.S.; Writing—review \& editing, G.Z. All authors have read and agreed to the published version of the manuscript.

Funding: This research was funded by National Natural Science Foundation of China, grant number 22005144; Natural Science Foundation of Jiangsu Province, grant number BK20200471.

Institutional Review Board Statement: Not applicable.

Conflicts of Interest: The authors declare that they have no known competing financial interest or personal relationships that could have appeared to in fluence the work reported in this paper.

\section{References}

1. Bakker, K. Water Security: Research Challenges and Opportunities. Science 2012, 337, 914-915. [CrossRef] [PubMed]

2. Petit, C.; Dias, E.M. Towards the use of metal-organic frameworks for water reuse: A review of the recent advances in the field of organic pollutants removal and degradation and the next steps in the field. J. Mater. Chem. A Mater. Energy Sustain. 2015, 3 , 22484-22506.

3. Abdel-Salam, O.E.; Abou Taleb, E.M.; Afify, A.A. Electrochemical treatment of chemical oxygen demand in produced water using flow-by porous graphite electrode. Water Environ. J. 2018, 32, 404-411. [CrossRef]

4. Bykovsky, N.A.; Bykovsky, N.A.; Kantor, E.A.; Rahman, P.A.; Puchkova, L.N.; Fanakova, N.N. Electrochemical treatment of waste water from nickel in galvanic production. IOP Conf. Ser. Earth Environ. Sci. 2019, 350, 12026-12029. [CrossRef]

5. Saranya, B.; Kanaga, P. Waste Water Treatment by Electrochemical Oxidation of Organic Pollutants. Res. J. Eng. Technol. 2019, 10, 50-54. [CrossRef]

6. Huang, J.; Wang, X.; Pan, Z.; Li, X.; Ling, Y.; Li, L. Efficient degradation of perfluorooctanoic acid (PFOA) by photocatalytic ozonation. Chem. Eng. J. 2016, 296, 329-334. [CrossRef]

7. Wu, Y.; Su, R.; Li, Y.; Wang, Z.; Lu, Z.; Xu, L.; Wei, B. Redox sculptured dual-scale porous nickel-iron foams for efficient water oxidation. Electrochim. Acta 2019, 309, 415-423. [CrossRef]

8. Cui, X.; Zhou, D.; Fan, W.; Huo, M.; Crittenden, J.; Yu, Z.; Ju, P.; Wang, Y. The effectiveness of coagulation for water reclamation from a wastewater treatment plant that has a long hydraulic and sludge retention times: A case study. Chemosphere 2016, 157, 224-231. [CrossRef]

9. Pan, C.; Troyer, L.; Catalano, J.; Giammar, D. Dynamics of Chromium(VI) Removal from Drinking Water by Iron Electrocoagulation. Environ. Sci. Technol. 2016, 50, 13502-13510. [CrossRef]

10. Yang, G.; Tang, L.; Zeng, G.; Cai, Y.; Tang, J.; Pang, Y.; Zhou, Y.; Liu, Y.; Wang, J.; Zhang, S.; et al. Simultaneous removal of lead and phenol contamination from water by nitrogen-functionalized magnetic ordered mesoporous carbon. Chem. Eng. J. 2015, 259, 854-864. [CrossRef]

11. Horovitz, I.; Gitis, V.; Avisar, D.; Mamane, H. Ceramic-based photocatalytic membrane reactors for water treatment-Where to next. Rev. Chem. Eng. 2020, 36, 593-622. [CrossRef]

12. Ali, P.I.; Asim, M.; Khan, T.A. Low Cost Adsorbents for Removal of Organic Pollutants from Wastewater. J. Environ. Manag. 2012, 113C, 170-183. [CrossRef]

13. Bora, T.; Dutta, J. Applications of Nanotechnology in Wastewater Treatment-A Review. J. Nanosci. Nanotechnol. 2014, 14, 613-626. [CrossRef] [PubMed]

14. Chen, X.; Cui, J.; Xu, X.R.; Sun, B.J.; Zhang, L.; Dong, W.; Chen, C.T.; Sun, D.P. Bacterial cellulose/attapulgite magnetic composites as an efficient adsorbent for heavy metal ions and dye treatment. Carbohydr. Polym. 2020, 229, 115512. [CrossRef] [PubMed] 
15. Zhu, P.; Tan, L.; Liu, J.; Tan, B.; Yang, X.; Xu, H. Triptycene-Based Hyper-Cross-Linked Polymer Sponge for Gas Storage and Water Treatment. Macromolecules 2015, 48, 8509-8514.

16. Kumar, P.; Pournara, A.; Kim, K.; Bansal, V.; Rapti, S.; Manos, M. Metal-organic frameworks: Challenges and opportunities for ion-exchange/sorption applications. Prog. Mater. Sci. 2017, 86, 25-74. [CrossRef]

17. Peng, Y.; Huang, H.; Zhang, Y.; Kang, C.; Chen, S.; Song, L.; Liu, D.; Zhong, C. A versatile MOF-based trap for heavy metal ion capture and dispersion. Nat. Commun. 2018, 9, 187. [CrossRef]

18. Serre, C.; Millange, F.; Thouvenot, C.; Nogues, M.; Marsolier, G.; Louer, D.; Ferey, G. Very Large Breathing Effect in the First Nanoporous Chromium(III)-Based Solids: MIL-53 or CrIII(OH) $\left\{\mathrm{O}_{2} \mathrm{C}-\mathrm{C}_{6} \mathrm{H}_{4}-\mathrm{CO}_{2}\right\} \cdot\left\{\mathrm{HO}_{2} \mathrm{C}-\mathrm{C}_{6} \mathrm{H}_{4}-\mathrm{CO}_{2} \mathrm{H}\right\}_{\mathrm{x}} \cdot \mathrm{H}_{2} \mathrm{O}_{\mathrm{y}}$. J. Am. Chem. Soc. 2002, 124, 13519-13526. [CrossRef]

19. Loiseau, T.; Serre, C.; Huguenard, C.; Fink, G.; Taulelle, F.; Henry, M.; Bataille, T.; Férey, G. A Rationale for the Large Breathing of the Porous Aluminum Terephthalate (MIL-53) Upon Hydration. Chem. A Eur. J. 2004, 10, 1373-1382. [CrossRef]

20. Ke, F.; Qiu, L.; Yuan, Y.; Jiang, X.; Zhu, J. Fe $\mathrm{O}_{4} @ \mathrm{MOF}$ core-shell magnetic microspheres with a designable metal-organic framework shell. J. Mater. Chem. 2012, 22, 9497-9500. [CrossRef]

21. Chan, X.C.A.N. $\mathrm{Fe}_{3} \mathrm{O}_{4} @ \mathrm{MOF}$ core-shell magnetic microspheres for magnetic solid-phase extraction of polychlorinated biphenyls from environmental water samples. J. Chromatogr. A 2013, 1304, 241-245. [CrossRef]

22. Shi, Z.; Xu, C.; Guan, H.; Li, L.; Fan, L.; Wang, Y.; Liu, L.; Meng, Q.; Zhang, R. Magnetic Metal Organic Frameworks (MOFs) Composite for Removal of Lead and Malachite Green in Wastewater. Colloids Surf. A Physicochem. Eng. Asp. 2017, 539, 382-390. [CrossRef]

23. Liu, Y.; Huang, Y.; Xiao, A.; Qiu, H.; Liu, L. Preparation of Magnetic $\mathrm{Fe}_{3} \mathrm{O}_{4}$ /MIL-88A Nanocomposite and Its Adsorption Properties for Bromophenol Blue Dye in Aqueous Solution. Nanomaterials 2019, 9, 51. [CrossRef]

24. Lin, X.; Li, Y.; Qi, M.; Tang, Z.; Jiang, H.; Xu, Y. A unique coordination-driven route for the precise nanoassembly of metal sulfides on metal-organic frameworks. Nanoscale Horiz. 2020, 5, 714-719. [CrossRef] [PubMed]

25. Zhang, S.; Xia, W.; Yang, Q.; Kaneti, Y.V.; Xu, X.; Alshehri, S.M.; Ahamad, T.; Hossain, M.S.A.; Na, J.; Tang, J.; et al. Core-shell motif construction: Highly graphitic nitrogen-doped porous carbon electrocatalysts using MOF-derived carbon@COF heterostructures as sacrificial templates. Chem. Eng. J. 2020, 396, 125154. [CrossRef]

26. Mantulnikovs, K.; Glushkova, A.; Kollár, M.; Forró, L.; Horváth, E.; Sienkiewicz, A. Differential Response of the Photoluminescence and Photocurrent of Polycrystalline $\mathrm{CH}_{3} \mathrm{NH}_{3} \mathrm{PbI}_{3}$ and $\mathrm{CH}_{3} \mathrm{NH}_{3} \mathrm{PbBr}_{3}$ to the Exposure to Oxygen and Nitrogen. ACS Appl. Electron. Mater. 2019, 1, 2007-2017. [CrossRef]

27. Nadar, S.S.; Vaidya, L.; Rathod, V.K. Enzyme embedded metal organic framework (enzyme-MOF): De novo approaches for immobilization. Int. J. Biol. Macromol. 2020, 149, 861-876. [CrossRef]

28. Chen, L.; Jiang, Y.; Huo, H.; Liu, J.; Li, Y.; Li, C.; Zhang, N.; Wang, J. Metal-organic framework-based composite Ni@MOF as Heterogenous catalyst for ethylene trimerization. Appl. Catal. A Gen. 2020, 594, 117457. [CrossRef]

29. Li, J.; Xia, W.; Tang, J.; Tan, H.; Wang, J.; Kaneti, Y.V.; Bando, Y.; Wang, T.; He, J.; Yamauchi, Y. MOF nanoleaves as new sacrificial templates for the fabrication of nanoporous $\mathrm{Co}-\mathrm{Nx} / \mathrm{C}$ electrocatalysts for oxygen reduction. Nanoscale Horiz. 2019, 4, 1006-1013. [CrossRef]

30. Qian, X.; Yadian, B.; Wu, R.; Long, Y.; Zhou, K.; Zhu, B.; Huang, Y. Structure stability of metal-organic framework MIL-53 (Al) in aqueous solutions. Int. J. Hydrog. Energ. 2013, 38, 16710-16715. [CrossRef]

31. Zhang, J.; Li, F.; Li, G.; Zhou, M.; Wu, Y.N.; Qiao, J.; McDonald, A. The removal of bisphenol A from aqueous solutions by MIL-53(Al) and mesostructured MIL-53(Al). J. Colloid Interf. Sci. 2013, 405, 157-163.

32. Zhu, L.; Lu, H.; Zhang, Z.; Jv, X.; Zhao, X. A Simplified Method for Synthesis of 1-Tyrosine Modified Magnetite Nanoparticles and Its Application for the Removal of Organic Dyes. J. Chem. Eng. Data ACS J. Data 2017, 62, 4279-4287.

33. Bhatnagar, A.; Anastopoulos, I. Adsorptive removal of bisphenol A (BPA) from aqueous solution: A review. Chemosphere 2017, 168, 885-902. [CrossRef]

34. Yang, C.; Qi-bin, S.; Zi-dan, L.; Xiao-ying, Y.; Tai-ping, Z.; Zhi-zhong, L. Preparation of Two Kinds of Biochar and the Factors Influencing Tetracycline Removal from Aqueous Solution. Environ. Sci. 2019, 40, 1328-1336.

35. Liu, J.; Li, H.; Xiong, Z. Removal of bisphenol A in aqueous solutions by core-shell magnetic molecularly imprinted polymers. Environ. Sci. 2013, 34, 2240-2248.

36. Li, P.; Chen, J.; Zhang, J.; Wang, X. Water Stability and Competition Effects toward $\mathrm{CO}_{2}$ Adsorption on Metal Organic Frameworks. Sep. Purif. Rev. 2015, 44, 19-27. [CrossRef]

37. Zhao, S.; Chen, D.; Wei, F.; Chen, N.; Liang, Z.; Luo, Y. Synthesis of graphene oxide/metal-organic frameworks hybrid materials for enhanced removal of Methylene blue in acidic and alkaline solutions. J. Chem. Technol. Biotechnol. 2018, 93, 698-709. [CrossRef]

38. Zhao, S.; Ding, C.; Wei, F.; Chen, N.; Liang, Z.; Luo, Y. Removal of Congo red dye from aqueous solution with nickel-based metal-organic framework/graphene oxide composites prepared by ultrasonic wave-assisted ball milling. Ultrason. Sonochem. 2017, 39, 845-852. [CrossRef]

39. Rameshraja, D.; Srivastava, V.C.; Kushwaha, J.P.; Mall, I.D. Quinoline adsorption onto granular activated carbon and bagasse fly ash. Chem. Eng. J. 2012, 181, 343-351. [CrossRef]

40. Li, C.; Xiong, Z.; Zhang, J.; Wu, C. The Strengthening Role of the Amino Group in Metal-Organic Framework MIL-53 (Al) for Methylene Blue and Malachite Green Dye Adsorption. J. Chem. Eng. Data 2015, 60, 3414-3422. [CrossRef] 
41. Yu, J.; Xiong, W.; Li, X.; Yang, Z.; Cao, J.; Jia, M.; Xu, R.; Zhang, Y. Mn-doped zirconium metal-organic framework as an effective adsorbent for removal of tetracycline and $\mathrm{Cr}(\mathrm{VI})$ from aqueous solution. Micropor. Mesopor. Mater. 2019, 290, 109642. [CrossRef]

42. Xie, J.X.; Chen, W.J.; Wu, Y.Y.; Wu, X.X.; Zhao, Q.R. Highly efficient adsorption capacity of MIL-53(Fe) metal organic framework material for congo red. Ind. Water Treat. 2017, 37, 27-30.

43. Park, J.M.; Jhung, S.H. A remarkable adsorbent for removal of bisphenol S from water: Aminated metal-organic framework, MIL-101-NH $\mathrm{N}_{2}$. Chem. Eng. J. 2020, 396, 125224. [CrossRef]

44. Wang, Y.; Gong, S.; Li, Y.; Li, Z.; Fu, J. Adsorptive removal of tetracycline by sustainable ceramsite substrate from bentonite/red mud/pine sawdust. Sci. Rep. UK 2020, 10, 1-18. [CrossRef]

45. Chen, Z.; Liu, Z.; Hu, J.; Cai, Q.; Li, X.; Wang, W.; Faraj, Y.; Ju, X.; Xie, R.; Chu, L. ß-Cyclodextrin-modified graphene oxide membranes with large adsorption capacity and high flux for efficient removal of bisphenol A from water. J. Membr. Sci. 2020, 595, 117510. [CrossRef]

46. Topuz, F.; Holtzl, T.; Szekely, G. Scavenging organic micropollutants from water with nanofibrous hypercrosslinked cyclodextrin membranes derived from green resources. Chem. Eng. J. 2021, 419, 129443. [CrossRef]

47. Ren, X.; Xiong, Z. Adsorption Behavior of Three Nitroimidazoles in Aqueous Solutions to Magnetic-modified Multi-walled Carbon Nanotubes. Acta Chim. Sinica 2013, 71, 625. [CrossRef]

48. Wo, R.; Li, Q.; Zhu, C.; Zhang, Y.; Qiao, G.; Lei, K.; Du, P.; Jiang, W. Preparation and Characterization of Functionalized Metal-Organic Frameworks with Core/Shell Magnetic Particles $\left(\mathrm{Fe}_{3} \mathrm{O}_{4} @ \mathrm{SiO}_{2} @ \mathrm{MOFs}\right)$ for Removal of Congo Red and Methylene Blue from Water Solution. J. Chem. Eng. Data 2019, 64, 2455-2463. [CrossRef] 